Original scientific paper - Izvorni znanstveni rad

UDK: 636.234 .2

\title{
Evaluation of the heritability coefficients of longevity in the population of Black and White cows in Serbia
}

doi: $10.15567 /$ mljekarstvo.2016.0408

\author{
Dragan Stanojević ${ }^{1}$, Radica Đedović ${ }^{1}$, Vladan Bogdanović ${ }^{1}$, Nikola Ragužž ${ }^{*}$, \\ Mladen Popovac ${ }^{1}$, Dobrila Janković ${ }^{3}$, Ljuba Śtrbac ${ }^{3}$ \\ ${ }^{1}$ University of Belgrade, Faculty of Agriculture, Nemanjina 6, 11080 Zemun, Serbia \\ ${ }^{2}$ Josip Juraj Strossmayer University of Osijek, Faculty of Agriculture, \\ Kralja Petra Svačića 1d, 31000 Osijek, Croatia \\ ${ }^{3}$ University of Novi Sad, Faculty of Agriculture, \\ Trg Dositeja Obradovića 8, 21000 Novi Sad, Serbia
}

Received - Prispjelo: 21.03.2016. Accepted - Prihvaćeno: 20.10.2016.

\begin{abstract}
Assessment of the heritability coefficients of longevity traits in the population of Black and White cows was performed on a data set that included production results of 16,539 of black and white culled cows, which reached a total of 50,382 lactations in the period from 1985 to 2012. The cows were grown on 7 farms of the Agricultural Corporation Belgrade and are progeny of 277 bulls. The analysis covered the following traits: length of productive life (LPL), lifetime milk yield (LMY) and number of lactations (NL). Variance components of longevity traits were estimated using a BLUP linear mixed model with animal as a random effect. Cows included in the analysis calved for the first time in the average age of 26.86 months, while the average length of productive life amounted to $1,299.9$ days and during that time the animals achieved an average of 3.04 lactations and life time production of $21,016 \mathrm{~kg}$ of milk. The values of the heritability coefficients of longevity traits ranged from $0.066 ; 0.061$ and 0.074 regarding the length of productive life, lifetime milk yield and number of lactations respectively.
\end{abstract}

Key words: heritability, longevity, Black and White cows

\section{Introduction}

High milk yield, as a result of conducted selection in milk production traits, resulted in an increase in production costs, which arise at the expense of reduced fertility, resistance and overall functionality of the organism of dairy cows (Pryce and Veerkamp, 1999). In support of this assertion are the published results of the research conducted by Dunkle et al. (1994) and Jones et al. (1994), which showed that superior livestock require higher levels of care and have higher medical costs, in milk production, i.e. the incidence of disorders such as ketosis, mastitis and reproductive problems is higher in highly-productive cows.
One of the most important tasks of modern breeding programs, implemented with dairy cattle, is the increase in the profitability of production (Ess1, 1998). Many factors affect the profitability of milk production. In the last decade of the twentieth century and the first decade of twenty-first century, a large number of studies (Allaire and Gibson, 1992; Dekkers, 1993; Smith et al., 2000; Harder et al., 2006; Orpin and Esslemont, 2010) showed that a high level of involuntary culled animals from production have a negative impact on the profitability of milk production on farms, that is longevity traits are strongly dependent on the profitability of milk production (Beaudeau et al., 2000). For this reason, today's breeding programs are designed with

*Corresponding author/Dopisni autor: E-mail: nraguz@pfos.hr 
the aim of improving longevity traits through direct selection. In most situations, the decision on culling animals from production is an economic decision made by the farmer, where he evaluates whether the livestock which will replace the culled one will be more profitable (Van Arendonk, 1988).

Pogačar et al. (1998) stated that longevity, as a function of livestock constitution and resistance to various diseases, with high productivity and good milk composition, is a very important trait for a profitable milk production. In accordance with these findings and in order to resolve the problems related to unwanted removal of livestock, a large number of countries include functional traits (Sewall et al., 2008) in their models for breeding value evaluation. This approach in selection has led to defining breeding programs which have moved the focus of selection from milk traits to significantly more balanced access to a larger number of traits, which also include functional traits (Miglior et al., 2005). Thus, today, 21 members of the Interbull practice genetic evaluation of longevity traits in dairy cattle populations (Interbull, 2015).

In previous period, longevity traits were defined in different ways. That is why White and Nichols (1965) observed longevity of dairy cattle through the number of lactations achieved by the animals. Everett et al. (1976) introduced the term stayability, which will later be used in a number of studies. The term stayability, as defined by these authors, is the ability of the livestock to survive a certain age, i.e. a period in the productive life. They have defined the stayability as five traits, i.e. they have monitored the stayability of the livestock at the 36,48 , 60, 72 and 84 months of age. Thus defined traits belong to the group of binary traits. Ducrocq (1987) found in his study that defining longevity traits on a continuous time scale is a more appropriate method for recording and analysing these traits, i.e. through the analysis of thus defined traits we receive higher heritability values. After this study, a larger number of authors (Roxström and Strandberg, 2002; Van der Linde et al., 2006; Forabosco et al., 2006; Potočnik et al., 2011; Raguž et al., 2012) used in their research traits defined in this way, traits such as length of productive life or duration of functional productive life.

The aim of this research is to estimate, for the first time, the heritability of longevity traits in the population of Black and White cattle in Serbia. Based on the results of this study, the breeding objectives and selection criteria for longevity traits should be defined and the integrated in the breeding program for this breed in Serbia.

\section{Materials and method}

The analysis was conducted on a data set which included production results of 16,539 animals of the Black and White breed, which had generated a total of 50,382 lactations. The average share of HolsteinFriesian genes in the analysed population is $78 \%$. The cows included in the analysis represent the highest portion of Black and White cows grown in Central Serbia. The animals are grown on 7 typical farms, with a large number of facilities where the animals are kept in a tied system grouped by production stage. The farms conduct a joint program of nutrition and health care. Most of the population of black and white cattle in Central Serbia, grown on this 7 farms.

The original data set included production results and information on the origin of 23,258 animals. Animals that still produced at the time of the formation of the data set were removed from the initial set, as well as animals for which we did not know the production for all lactations or unknown date of first calving. We also excluded from the data set the animals that calved for the first time at the age below 20 or above 40 months. All the livestock included in the analysis had a known date of first calving and date of culling as well as first calving in the period from October 1985 to May 2012 that is, all the animals were culled at the time of analysis.

The analysis includes the following traits:

- length of productive life (LPL) - time period between the first calving and culling of the animal expressed in days;

- lifetime milk yield (LMY) - total amount of produced milk during the productive life expressed in kg;

- number of lactation (NL) - represents the total number of lactations achieved by cow.

Besides the traits of longevity we calculated the animal survival rate in relation to lactation in order of the methodology proposed by the Nieuwhof at al. (1989). Survival rate for the first lactation was set at $100 \%$ (all animals included in the analysis 
had at least start of first lactation) upon which an animal "survived" until the next lactation if date of its subsequent calving had been recorded as well as its performance in a subsequent lactation. A certain number of cows was culled immediately upon calving and a start of lactation and in all the animals culled in the first 30 days of lactation the date of the last drying off was taken as a date of culling. Survival rate for subsequent lactations was calculated as a relation of the number of animals which realised given lactation and the number of animals which realised the first lactation $(16,572)$. A total number of realised lactations was 50,382 , where each cow included in the analysis realised between 1 and 8 lactations.

The values of genetic and phenotypic variances were calculated using the REML procedure (VCE, v6.0, 2010) (single trait method) and by using the following mixed model:

$$
\begin{aligned}
\text { Yijklmno }= & \mu+\mathrm{Fi}+\mathrm{Gj}+\mathrm{Sk}+\mathrm{Ul}+\mathrm{Hm}+ \\
& \mathrm{Dn}+\mathrm{ao}+\text { eijklmno, }
\end{aligned}
$$

Where:

Yijklmno - phenotypic manifestation of longevity traits,

$\mu$ - general population mean,

$\mathrm{Fi}$ - fixed effect of the i farm

$\mathrm{Gj}$ - fixed effect of the $\mathrm{j}$ year of $1^{\text {st }}$ calving,

Sk - fixed effect of the season of $1^{\text {st }}$ calving,

U1 - fixed effect of the age at first calving,

$\mathrm{Hm}$ - fixed effects of share Holstein genes

$D_{n}$ - the fixed effect of relative milk production in $1^{\text {st }}$ lactation,

$a_{o}$ - random genetic effect of animal,

$\mathrm{e}_{\mathrm{ijklmno}}$ - random error.

Year is divided into 4 seasons: winter season (December, January, February), spring season (March, April, May), summer season (June, July, August) and autumn season (September, October, November).
Age at first calving divided into 10 classes in the following way: I - age at first calving less than 22 months, II - age at first calving from 22 to 24 months, III - age at first calving from 24 to 26 months, IV age at first calving from 26 to 28 months, V - age at first calving from 28 to 30 months, VI - age at first calving from 30 to 32 months, VII - age at first calving from 32 to 34 months, VIII - age at first calving from 34 to 36 months, IX - age at first calving from 36 to 38 months, $\mathrm{X}$ - age at first calving from 38 to 40 months.

Depending on the share of genes Holstein al cows divided in five classes: I - less than $50 \%$ Holstein genes, II - from 50 to $75 \%$ Holstein genes, IIIfrom 75 to $87.5 \%$ Holstein genes, IV - from 87.5 to $93.75 \%$ Holstein genes, $\mathrm{V}$ - more than $93.75 \%$ Holstein genes.

All fixed factors included in the model were statistically highly significant impact on the observed longevity traits.

Using linear models, the heritability was calculated using following formulas:

$$
\begin{aligned}
& \boldsymbol{h}^{2}=\frac{\sigma_{a}^{2}}{\sigma_{a}^{2}+\sigma_{a}^{2}}, \\
& \text { where: }
\end{aligned}
$$

$\boldsymbol{h}^{\mathbf{2}}$ - the coefficient of heritability for longevity traits, $\sigma_{a}^{\mathbf{2}}$ - additive genetic variance, $\sigma_{a}^{\mathbf{2}}$ - environmental variance.

\section{Results and discussion}

Cows included in the analysis calved for the first time in the average age of 26.86 months. The average length of productive life amounted to 1299.94 days and during that time the animals achieved an average of 3.04 lactations and produced a total of $21016 \mathrm{~kg}$ of milk. Average values and variability of

\begin{tabular}{|c|c|c|c|c|c|c|}
\hline Trait & $\mathrm{n}$ & $\bar{x}$ & SD & CV $(\%)$ & $\min$ & $\max$ \\
\hline LPL (days) & \multirow{4}{*}{16539} & 1299.94 & 763.81 & 58.75 & 98 & 3939 \\
\hline LMY (kg) & & 21.016 & 13.649 & 64.94 & 1708 & 99816 \\
\hline NL & & 3.04 & 1.81 & 59.54 & 1 & 8 \\
\hline Age at $1^{\text {st }}$ calving (months) & & 26.86 & 3.17 & 11.74 & 20 & 40 \\
\hline
\end{tabular}
longevity traits achieved by the cows included in the research are showed in Table 1.

Table 1. Average values and variability of longevity traits 
The determined values for the average length of productive life and number of lactations were higher than the values found in research by Raguž et al. (2014) in a population of Holstein cows in Croatia. Lower values for the length of productive life were also found by Nienartowicz-Zdrojewski et al. (2009) and M'hamdi et al. (2010). Similar values in observed longevity traits were found by Hoque and Hodges (1980).

The LPL and LMY are not normally distributed traits (Figures 1 and 2).

Figures 3 and 4 show a graphical representation of the group influence according to their shares of the Holstein gene on LPL and LMY.

If we analyse the impact of the share of Holstein-Friesian genes on LPL and LMY, we notice an

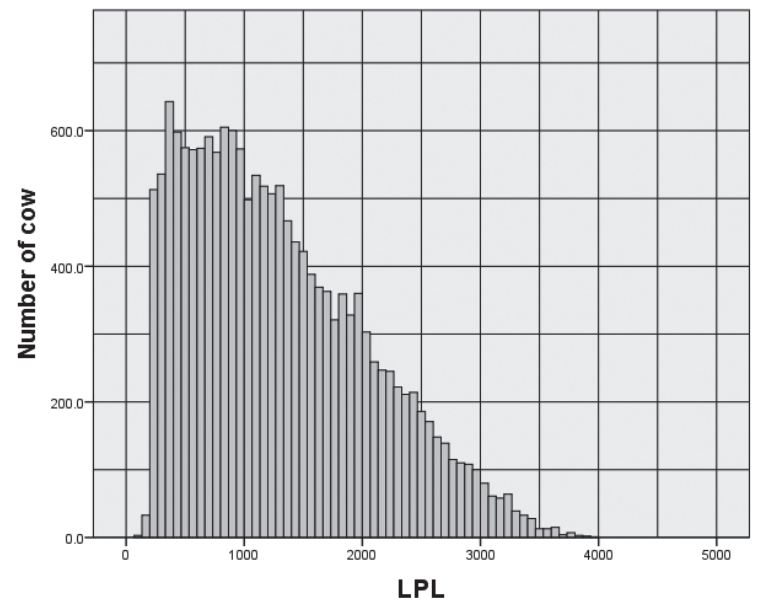

Figure 1. Distribution of the LPL

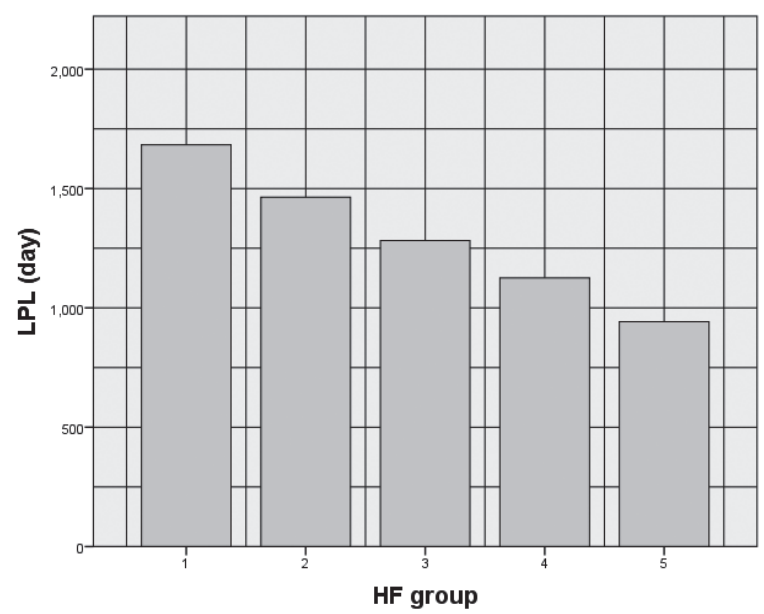

Figure 3. Impact of gene share of Holstein breed on LPL almost identical trend. Namely, an increase in the share of HF genes leads to shortening the length of productive life and reduction of lifetime milk yield. This trend can be explained by the fact that through an increase of the share of Holstein-Friesian gene, the constitution of the animal weakens, we get highyield dairy cattle but whose resistance is reduced (Ingvartsen et al., 2003). These animals are more prone to reproductive disorders (25\%), feet and legs (and metabolic disorders (11\%), and are culled from production earlier. Also, we must not neglect the interaction of the genotype and environmental factors, primarily ways of keeping the animals (tied system, inadequate feeding, and the overall approach to production with significantly more demanding livestock units). An increase in the share of Holstein-Friesian

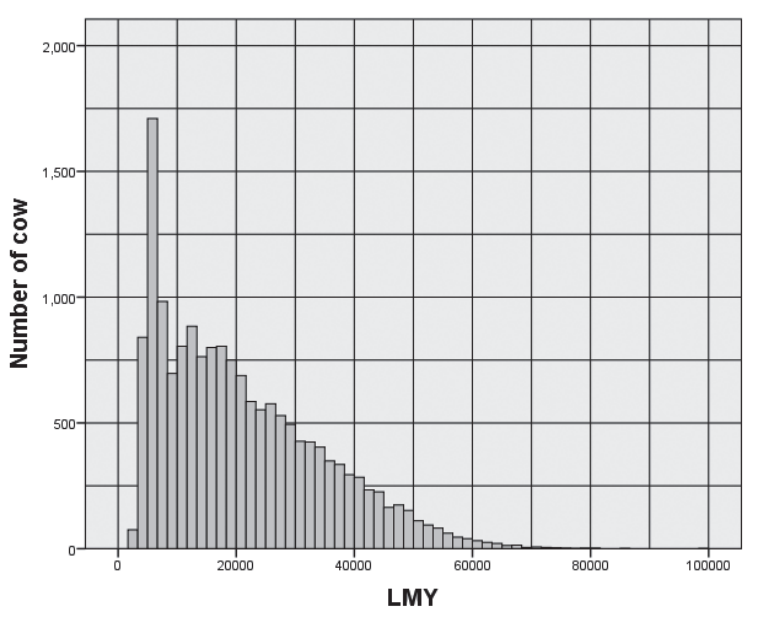

Figure 2. Distribution of the LMY

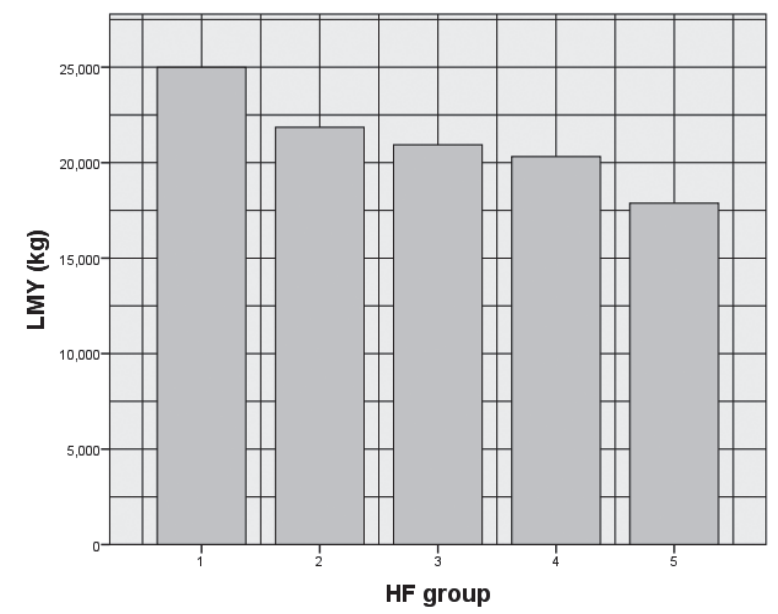

Figure 4. Impact of gene share of Holstein breed on LMY 
genes does not have such a drastic impact on milk yield, as opposed to the length of productive life. Cows with a greater proportion of Holstein-Friesian genes have higher milk production. Although they will potentially achieve a smaller number of lactations, the milk yield in these lactations will be higher due to an increased share of Holstein-Friesian genes, which will partly alleviate that effect. Recorded a small number of lactation at the cows with a higher proportion of genes Holstein-Friesian breed, may be the result of negative interactions between genotype and environmental factors. The impact of the year of first calving on the length of productive life and lifetime milk yield is shown in Figures 5 and 6.

The dramatic drop in the length of productive life starting from the mid-eighties is probably the result of the aforementioned increase in the share of Holstein-Friesian genes, i.e. intensive use of purebred breeding bulls of this breed. Besides

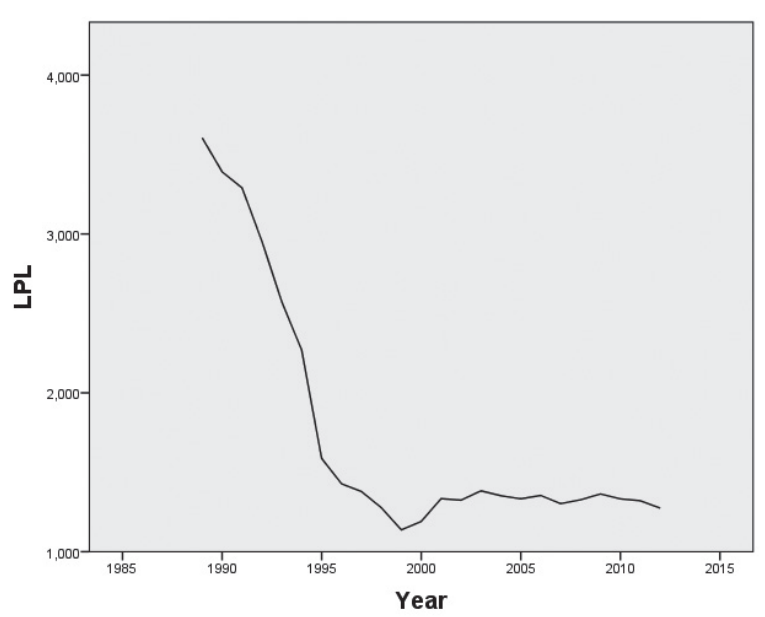

Figure 5. Impact of year at first calving on LPL this fact, the drop in the length of productive life was influenced by the severe economic crisis in the early nineties, which resulted in very complex market conditions that brought the production of the PKB Corporation to a very difficult position. The lifetime milk yield had the opposite trend compared to the length of productive life. In contrast to the reduction in the length of productive life, lifetime milk yield has grown as a result of increased share of Holstein-Friesian genes and increase in milk production of dairy cows. Since the mid-nineties, this trend has become negative, most likely as a result of the difficult economic situation and economic sanctions Yugoslavia faced then. In the picture we can see that lifetime milk yield is growing, from the beginning of the $21^{\text {st }}$ century, as a result of consolidated production and application of modern technological processes in the production of milk. Survival rate values are shown in Table 2:

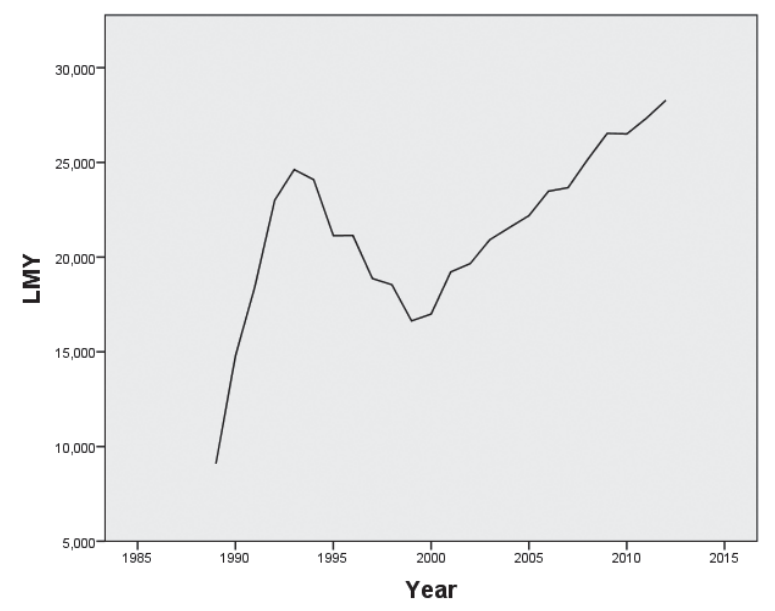

Figure. 6. Impact of year at first calving on LMY

Table 2. Survival rates

\begin{tabular}{ccccccccc}
\hline Lactation & I & II & III & IV & V & VI & VII & VIII \\
\hline Survival rate (\%) & 100 & 75.82 & 53.32 & 35.12 & 21.58 & 11.46 & 5.21 & 1.76 \\
\hline
\end{tabular}

Table 3. Coefficients of heritability of longevity traits

\begin{tabular}{ccccc}
\hline Traits & $\sigma_{a}^{2}$ & $\sigma_{\vec{a}}^{2}$ & $\mathrm{~h}^{2}$ & $\mathrm{SE}_{\mathrm{h}}{ }^{2}$ \\
\hline LPL & 25467.2 & 383011 & 0.0664 & 0.011 \\
\hline LMY & 9016437 & 134300000 & 0.0671 & 0.010 \\
\hline NL & 0.16022 & 2.16356 & 0.0740 & 0.012 \\
\hline
\end{tabular}


The values of the stayability coefficient indicate that the largest number of dairy cattle is culled from production during the first three lactations. Nearly half of the dairy cows population in the study is culled during the first and second lactation, while a bit less than $2 \%$ of the livestock finished eighth lactation. The largest part of the first lactation cullings were unvoluntary cullings (about $90 \%$ ), primarily caused by reproductive disorders (29.8\%), mastitis $(14.35 \%)$ and problems with feet and hooves $(9.85 \%)$. This can be linked to the unilateral selection for milk traits, which in the past had primacy when it comes to the selection in this population of dairy cattle, as well as the breeding technology implemented in analysed farms. A similar trend of culling was determined by Caraviello et al. (2004). Estimated heritabilities of longevity traits are shown in Table 3.

The heritabilities of longevity traits, estimated using a linear mixed model, had its value from 0.066 in terms of length of productive life, to 0.074 in the case of number lactations. Determined values of heritability for the length of productive life had higher values than the values in the research by Vollema and Groen (1996) and Boettcher et al. (1999). The differences in the values of determined heritability coefficients for the length of productive life can be the result of the model used by these authors. Namely, they used the sire model in their research. Higher values were found in the research by Raguz (2012), by using an animal model in comparison to the use of the sire model. Close values of heritability coefficient for the length of productive life were determined by Strandberg (1992), Raguz et al. (2014) and Lurdes Kern et al. (2014).

Considering lifetime milk yield, higher values of heritability for this trait were determined by Hoque and Hodges (1980) and Vollema and Groen (1996) in the population of Black and White cattle in the Netherlands. Lower values of heritability for the observed trait were determined by Lurdes Kern et al. (2014) in the population of Holstein-Friesian cows in Brazil. Established value of heritability for the number of lactations was higher than the value found in the study by Vollema and Groen (1996), while Jairath et al. (1994) established a close heritability value of the observed trait.

\section{Conclusion}

The results of the study showed that the phenotypic expression and variability of longevity traits are influenced by numerous factors, such as the farm where the animal produced, the first calving year and season, share of genes of the Holstein-Friesian breed and the age of first calving. The determined values of heritability for longevity traits indicate their low heritability and the dominant influence of environmental factors on their phenotypic expression and variation. Low heritability of this group of traits has resulted in reduced space for use of direct selection, as a method for improving this group of traits. As a possibility to overcome this situation it is necessary to consider the use of other methods for estimation of variance components for longevity traits, such as stayability analysis, which more adequately treats the very nature of the trait. In addition to the use of stayability analysis, it is necessary to examine the connection of longevity traits with other traits, such as the traits of the type that can be used as indicators when it comes to the selection of longevity traits. In this way, it can increase the selection effect of longevity traits by means of indirect selection.

\section{Acknowledgments}

The research has been financed by the Ministry for Science and Technological Development of the Republic of Serbia as part of the Project TR 31086.

\section{Procjena koeficijenata heritabiliteta svojstava dugovječnosti u populaciji crno-bijelih krava u Srbiji}

\section{Sažetak}

Koeficijenti heritabiliteta za svojstva dugovječnosti crno-bijelih krava procijenjeni su na podacima koji su uključivali proizvodnju 16.539 izlučenih krava s ukupno ostvarene 50.382 laktacije u razdoblju od 1985. do 2102. godine. Životinje su uzgajane na 7 farmi Poljoprivredne korporacije Beograd te su potomci 277 bikova. Analiza je obuhvaćala sljedeća svojstva: dužinu produktivnog vijeka, životnu količinu mlijeka i ukupan broj ostvarenih 
laktacija. Komponente varijance procijenjene su na temelju linearnog mješovitog modela pri čemu je svaka životinja promatrana kao slučajni utjecaj. Krave uključene $u$ analizu prvi su se puta telile $u$ prosječnoj dobi od 26,86 mjeseci, dok je prosječna dužina produktivnog vijeka iznosila 1.299,9 dana (3,56 godina). U tom razdoblju, krave su u prosjeku ostvarile 3,04 laktacije te ukupno proizvele 21.106 $\mathrm{kg}$ mlijeka. Vrijednosti heritabiliteta kretale su se od 0,0664 za dužinu produktivnog vijeka, 0.0671 za životnu proizvodnju mlijeka do 0.0740 za ukupan broj ostvarenih laktacija.

\section{Ključne riječi: koeficijenti heritabiliteta, dugovječnost, crno-bijele krave}

\section{References}

1. Allaire, F.R., Gibson, J.P. (1992): Genetic value of herd life adjusted for milk production, Journal of Dairy Science 75, 1349-1356. doi: 10.3168/jds.S0022-0302(92)77886-2

2. Beaudeau, F., Seegers, H., Ducrocq, V., Fourichon, C., Bareille, N. (2000): Effect of health disorders on culling in dairy cows: a review and a critical discussion, Annales de zootechnie, 49 (4), 293-311. doi: 10.1051/animres:2000102

3. Boettcher, P., Jairath, L.K., Dekkers, J.C.M. (1999): Comparison of methods for genetic evaluation of sires for survival of their daughters in the first three lactations, Journal of Dairy Science 82, 1034-1044. doi: 10.3168/jds.S0022-0302(99)75324-5

4. Caraviello, D.Z., Weigel, K.A., Gianola, D. (2004): Prediction of longevity breeding values for US Holstein sires using survival analysis methodology, Journal of Dairy Science 87, 3518-3525. doi: 10.3168/jds.S0022-0302(04)73488-8

5. Dekkers, J.C.M. (1993): Theoretical basis for genetic parameters of herd life and effects on response to selection, Journal of Dairy Science 76, 1433-1443. doi: 10.3168/jds.S0022-0302(93)77474-3

6. Ducrocq, V. (1987): An analysis of length of productive life in dairy cattle. Ph.D. thesis, Cornell Univ., Ithaca, NY, USA.

7. Dunklee, J.S., Freeman, A.E., Kelley, D.H. (1994): Comparison of Holsteins selected for high and average milk production. 2. Health and reproductive responses to selection for milk, Journal of Dairy Science 77, 3683-3690. doi: 10.3168/jds.S0022-0302(94)77313-6

8. Essl, A. (1998): Longevity in dairy cattle breeding: a review, Livestock Production Science 57, 79-89. doi: 10.1016/S0301-6226(98)00160-2
9. Everett, R.W., Keown, J.F., Clapp, E.E. (1976): Production and stayability trends in dairy cattle, Journal of Dairy Science 59, 1532-1539. doi: 10.3168/jds.S0022-0302(76)84399-8

10. Forabosco, F., Bozzi, R., Filippini, F., Boettcher, P., Van Arendonk, J.A.M., Bijma, P. (2006): Linear model vs. survival analysis for genetic evaluation of sires for longevity in Chianina beef cattle, Livestock Science 101 (1), 191-198. doi: 10.1016/j.livprodsci.2005.11.010

11. Groeneveld, E., Kovač, M., Mielenz, N. (2010): VCE v6.0. User's guide and reference manual. Version 6.0. ftp://ftp.tzv.fal.de/pub/vce6/doc/vce6-manual-3.1-A4. pdf.

12. Harder, B., Bennewitz, J., Hinrichs, D., Kalm, E. (2006). Genetic parameters for health traits and their relationship to different persistency traits in German Holstein dairy cattle, Journal of Dairy Science 89, 3202-3212. doi: 10.3168/jds.S0022-0302(06)72595-4

13. Hoque, M., Hodges, J. (1980): Genetic and phenotypic parameters of lifetime production traits in Holstein cows, Journal of Dairy Science 63, 1900-1910. doi: 10.3168/jds.S0022-0302(80)83157-2

14. Ingvartsen, K.L., Dewhurst, R.J., Friggens, N.C. (2003): On the relationship between lactational performance and health: is it yield or metabolic imbalance that causes diseases in dairy cattle? A position paper, Livestock Production Science 83, 277-308. doi: 10.1016/S0301-6226(03)00110-6

15. Interbull (2015): Description of national genetic evaluation systems for dairy cattle traits as applied in different Interbull member countries.

16. Jairath, L.K., Hayes, J.F., Cue, R.I. (1994): Multi-trait restricted maximum likelihood estimates of genetic and phenotypic parameters of lifetime performance traits for Canadian Holsteins, Journal of Dairy Science 77, 303-312. doi: 10.3168/jds.S0022-0302(94)76955-1

17. Jones, W.P., Hansen, L.B., Chester-Jones, H. (1994): Response of health care to selection for milk yield of dairy cattle, Journal of Dairy Science 77, 3137-3152. doi: 10.3168/jds.S0022-0302(94)77257-X

18. Lurdes Kern, E., Cobuci, J.A., Costa, C.N., Neto, J.B., Campos, G.S., McManus, C.M. (2014): Genetic parameters for longevity measures in Brazilian Holstein cattle using linear and threshold models, Archiv Tierzucht 57 (33), 1-12.

19. M'hamdi, N., Aloulou, R., Bouallegue, M., Satinder, K. B., Ben Hamouda, M. (2010): Study on functional longevity of Tunisian Holstein dairy cattle using a Weibull proportional hazard model, Livestock Science 132, 173-176. doi: 10.1016/j.livsci.2010.05.01 1

20. Miglior, F., Muir, B.L., Van Doormaal, B.J. (2005): Selection Indices in Holstein Cattle of Various Countries, Journal of Dairy Science 88, 1255-126. doi: 10.3168/jds.S0022-0302(05)72792-2

21. Nienartowicz-Zdrojewska, A., Dymarski, Z., Sobek, Z., Wolc, A. (2009): Culling reasons as related to lifetime dairy performance in Polish Friesian (Black-and-White) cows on Pawłowice farm in the years 1909-2006, Animal Science Papers and Reports 27 (3), 173-180. 
22. Nieuwhof, G. J., Norman, H.D., Dickinson, F.N. (1989): Phenotypic trends in herd life of dairy cows in the United States, Journal of Dairy Science 72, 726-736. doi: 10.3168/jds.S0022-0302(89)79166-9

23. Orpin P.G., Esslemont R.J. (2010): Culling and wastage in dairy herds: An update on incidence and economic impact in dairy herds in the UK, Cattle Practice 18, 163-172.

24. Orpin, P.G., Esslemont, R.J. (2010): Culling and wastage in dairy herds: An update on incidence and economic impact in dairy herds in the UK, Cattle Practice 18, 163-172.

25. Pogačar, J., Potočnik, K., Kump, I., Dolinar, A. (1998): Estimation of stayability traits in black-and-white cows in Slovenia. $6^{\text {th }}$ Int. Symp. "Animal Science Days", Portorož, Slovenia, Sept. 16-18, 1998.

26. Potočnik, K., Gantner, V., Krsnik, J., Štepec, M., Logar, B., Gorjanc, G. (2011): Analysis of longevity in Slovenian holstein cattle, Acta argiculturae Slovenica 98 (2), 93-100.

27. Raguž, N. (2012): Genetsko vrednovanje dugovječnosti u populaciji simentalske i holstein pasmine goveda $\mathrm{u}$ Hrvatskoj. Doktorska disertacija. Poljoprivredni fakultet Osijek.

28. Raguž, N., Jovanovac, S., Mészáros, G., Sölkner, J. (2014): Linear vs. piecewise Weibull model for genetic evaluation of sires for longevity in Simmental cattle, Mljekarstvo 64 (3), 141-149. doi: 10.15567/mljekarstvo.2014.0301

29. Roxström, A., Strandberg, E. (2002): Genetic analysis of functional, fertility-, mastitis-, and productiondetermined length of productive life in Swedish dairy cattle, Livestock Production Science 74, 125-135. doi: 10.1016/S0301-6226(01)00300-1
30. Sewalem, A., Miglior, F., Kistemaker, G.J., Sullivan, P., Van Doormaal, B.J. (2008): Relationship between reproduction traits and functional longevity in Canadian dairy cattle, Journal of Dairy Science 91, 1660-1668. doi: 10.3168/jds.2007-0178

31. Smith, J.W., Ely, L.O., Chapa, A.M. (2000): Effect of region, herd size, and milk production on reasons cows leave the herd, Journal of Dairy Science 83, 2980-2987. doi: 10.3168/jds.S0022-0302(00)75198-8

32. Strandberg, E. (1992): Lifetime performance in dairy cattle. Genetic parameters and expeeted improvement from selection. Acta Agric. Scand. A, Animal Science 42, 127-137.

33. Van Arendonk, J.A.M. (1988): Managment guides for insemination and replacement decisions, Journal of Dairy Science 71, 1050-1057. doi: 10.3168/jds.S0022-0302(88)79651-4

34. Van der Linde, C., De Jong, G., Simai, S., Gombacsi, P., Wellisch, P. (2006): Genetic evaluation for longevity in Hungary, Interbull Bulletin 35, 3.

35. Vollema, A.R., Groen, A.F. (1996): Genetic parameters of longevity traits of an upgrading population of dairy cattle, Journal of Dairy Science 79, 2261-2267. doi: 10.3168/jds.S0022-0302(96)76603-1

36. White, J.M., Nichols, J.R. (1965): Relationships between first lactation, later performance, and length of herd life in Holstein-friesian cattle, Journal of Dairy Science 48 (4), 468-474. doi: 10.3168/jds.S0022-0302(65)88254-6 